\title{
Assessment of Mung Bean (Vignaradiata) pests in the Low Land Areas of North Shewa Zone
}

\author{
Wulita Wondwosen
}

Amhara Regional Agricultural Research Institute, Bahir Dar, Ethiopia

\section{ABSTRACT}

Mung bean known locally as "Masho" is a recent introduction in the Ethiopian pulse production and grown in few areas of the country and constrained by different biotic factors.However, the relative importance of each pest across locations has not been assessed and well profiled to sound management strategy. The objective of this study was to assess distribution and intensity of major pests on mungbean. The survey was made in 2016 and 2017 main cropping seasons following the main roads and accessible routes in each survey district (lowland areas of North Shewa Zone) and stops were made at every 5-10 km intervals based on vehicles odometers as per mung bean fields available. Five stops were made in each mung bean field by moving " $X$ " fashion at each stop interval using quadrants and data were collected from each. The result indicated that, Apion clavipes was most prevalent insect pest of mung bean in surveyed areas with maximum prevalence of $100 \%$. Similarly, leaf blight and leaf spot were most prevalent diseases of mung bean in all districts. On the other hand, survey revealed that Cyperus spp. was frequently observed weed in both seasons with the highest weed density per $\mathrm{m} 2$. In 2017, weed Spps. Cyperus rotundus and Echinocloacolona L. were more frequently obtained weeds of mung bean in the surveyed districts with the consequent frequencies (77.42, 70.97\%) and densities (16.11, 2.8 per $\mathrm{m} 2$ ). The current study indicated that a complex of pests exist on mung bean in the studied areas. Therefore, pest management strategies need to be devised.

Keywords : Mung Bean, Pests, Assessment, Intensity, Prevalence

\section{INTRODUCTION}

Mung bean is one of the most important pulse crops, grown from the tropical to sub-tropical areas around the world (Kumari et al., 2012; Khan et al.,2012). The crop is characterized by fast growth under warm conditions, low water requirement and excellent soil fertility enhancement via nitrogen fixation (Yagoob and Yagoob 2014). Among legumes, mung bean is noted for its protein and lysine-rich grain, which supplements cereal-based diets (Minh 2014). The grain contains $24.2 \%$ protein, $1.3 \%$ fat and $60.4 \%$ carbohydrate (Hussainet al., 2011).Among pulses, mung bean is the most important cash crops in the world (Pandeyet al., 2011). It is a very important crop in developing countries where it is consumed as dry seeds, fresh green pods or leaves due to its high protein, vitamin and mineral content. It is also consumed as forage or green pods and seeds as vegetables (Das et al., 2014). Primarily, the purposes of this crop are for its protein rich edible seeds and fresh sprout. The seed of mung bean mainly used for making soups, bread and biscuits (Sehrawatet al., 2013). On the other hand, mung bean is importance legume to assistance in normal use of land, water resource and enrichment of the soil through nitrogen fixation. Adaptation to short growth duration, low water requirement, ability to increase soil fertility and usefulness in crop rotation practices are also other significances of mung bean (Das et al., 2014). 
And also, it has the Ability of improving soil fertility by fixing atmospheric nitrogen into available form with the help of rhizobia species for plant's growth and development are characters of mung bean (Jatet al., 2012).

According to ECX (ECX 2014), mung bean locally as "Masho" is being cultivated as a recently introduced crop in Ethiopia. In Ethiopia, mung bean is mostly grown by smallholder farmers under drier marginal environmental condition (Asratet al., 2012) and the production capacity is lower than other pulse crops. The volume of production is also very small and it is concentrated mainly in Amhara, SNNPR, Oromia regional states and in some woredas of Beneshalgu 1Gumuz region. Mung bean is a quick crop, requiring 75-90 days to mature. It is a useful crop in drier areas and has a good potential for crop rotation and relay cropping both fertile and marginal lands but prefers well-drained loam to sandy loam with $\mathrm{pH}$ ranging with cereals using residual moisture (Sisayet al., 2014). It can grow on a wide range of soils of Mung bean occupies close to $37,774.3$ ha of land with annual productivity about $1.14 \mathrm{t} / \mathrm{ha}$ in the country and in Amhara region, the crop covers an area of $28,992.86$ ha of land with productivity of $1.21 \mathrm{t} / \mathrm{ha}$ (CSA 2017).Likewise, the crop covered about $17,490.23$ ha of land with annual productivity of $1.22 \mathrm{t} / \mathrm{ha}$ in North Shewa Zone. The average yield of mung bean under small-holder farmers is not more than $1.1 \mathrm{t}$ ha- 1 in the country (CSA 2017). The low productivity of the crop is attributed to susceptibility to biotic and abiotic stresses. Biotic stresses are major factors limiting the yield and quality of mung bean. Of the biotic category, diseases, insect pests and weeds are important factors limiting the production of food-legume crops as a whole and mung bean specifically in Ethiopia, including Amhara region. The relative importance of each pest in the study area has not been assessed and well profiled to sound management strategy. Therefore, the objective of this study was to assess the distribution and intensity of major pests of mung bean in the lowland areas of North Shewa zone.

\section{MATERIALS AND METHODS}

The survey was conducted in 2016 and 2017 main cropping season in six major mung bean producing districts of North Shewa Zone Amhara Region. Mung bean fields were assessed randomly at intervals of 5$10 \mathrm{~km}$ along the main road as mung bean fields exist. A $1 \mathrm{~m}$ x $1 \mathrm{~m}$ square quadrate was used in ' $\mathrm{X}$ ' manner at two diagonals across the inspected fields. In each field, total plants within the quadrate were observed and plants were recorded as infected or healthy for diseases and insect pest's data. The mean prevalence, incidence and severity of insect pests and diseases of each field were computed.

Percent of occurrence (prevalence) $=$ (Number of fields with infected)/ (Total number of assessed fields) $\mathrm{x} 100$

Percent incidence (for insect pests and diseases) = (Number of plantes infected)/ (Total number of plants assessed) x 100

Disease severity of each disease was recorded in percentage (\%), while severity of insects was in 1-9 scale and finally converted to percentage (\%). The results of the survey were summarized by descriptive statics.

On the other hand, mung bean weeds were recorded as count per quadrate and expressed as frequency and density of species (Roger et al., 2015).

Frequency of each was calculated by the formula:

$$
\mathrm{Fi}=\left(\sum \mathrm{Zi}\right) / \mathrm{n}
$$

Where density of each weed was calculated as

$$
\mathrm{Di}=\left(\sum \mathrm{Yi}\right) /(\mathrm{Sa})
$$

Where: $\mathrm{Fi}=$ frequency value for species $\mathrm{i} ; \mathrm{Zi}$ $=$ number of sampling units with with weed, $\mathrm{n}=$ total 
number of sampling units surveyed; $\mathrm{Di}=$ density of species $\mathrm{Yi}=$ number of individual plants of species $\mathrm{i}$ contained in the sampling unit (quadrat or field); $\mathrm{Sa}=$ Surface area of the sampling unit.

\section{RESULTS AND DISCUSSION}

Survey results revealed that, the extent of mung bean pests' intensity were variable from field to field, district to district and season to season.In the main crop-growing season of 2016, seventeen (17) mung bean fields were assessed from 3 districts (Antsokia, Efratagidm and Kewet). On the other hand, in 2017 cropping season, 57 fields were surveyed from six districts (Antsokia, Efratagidm, Kewet,Ensaro, Merhabete and Midaweremo).

\section{A. Prevalence and Intensity of Mung Bean Diseases in Surveyed Areas}

In 2016, mung leaf blight, leaf spot and powdery mildew were prevalent diseases in assessed districts. All fields assessed in 2016 were infected with leaf blight. The corresponding, incidences and severities of $72,8 \% ; 19.85 \%, 6.17 \%$ and $33,8 \%$ were recorded from Antsokia, Efratagidm and Kewet districts. Similarly, the prevalence of leaf spot was higher (100\%) at Efratagidm district. Leaf spot incidences and severities $(95,11.5 ; 65.5,8.85$ and 56,25\%) were recorded from Antsokia, Efratagidm and Kewet districts, respectively. On the other hand, powdery mildew incidences of $12.5,17.14$ and $40 \%$ were recorded from Antsokia, Efratagidm and Kewet districts, respectively, with the corresponding severities of 5. 6.25 and 17.5\%. Likewise, in 2017,leaf blight was prevalent disease in all surveyed districts with maximum (57.14\%) prevalence at Merhabete district. Leaf blight, leaf spot and powdery mildew were observed on most of surveyed districts with consequent prevalence's of $33.33,44.44$ and $22.22 \%$ (at Antsokia), 20\% (at Efratagidm), 6.67,60 and 13,33\% (at kewet, 18.18,54.45 and 36.6\% (at Ensaro). Only leaf blight and root rot were obtained at Merhabete with mean prevalence of 57.14\% leaf blight and 14.29\% root rot. Generally, the most prevalent diseases of mung bean in the surveyed districts were leaf blight, leaf spot and powdery mildew. The result of this study is in agreement with (Ramanathan, et al., 2002; Srinives, 1996), who reported that most diseases of mung bean are leaf blight, leaf spot and powdery mildew. Poehlman, (1991), also stated leaf spot caused by (Cercospora canescens), powdery mildew(Erysiphe polygoni) are the most important diseases of mung bean.

The intensities of diseases were varied across locations and seasons. The result of this study is agreed with Boudreau and Mundt (1992), who reported that variation among environments, crops and cropping regime brings about simultaneous variation in diseases and their intensities. The prevalence's of leaf blight, leaf spot and powdery mildew were higher in 2016 tan 2017. This might be due to favorable weather condition in 2016. Leaf blight disease was most prevalent disease in 2016 and it was observed on all surveyed fields. Suliet al., (2017) reported that ,mung bean blight has been rapidly spreading and is prevalent in the three major mung bean- producing regions of China.

Table 1: prevalence's and severities of mung bean diseases in the surveyed districts

\begin{tabular}{|c|c|c|c|c|c|c|c|c|}
\hline \multicolumn{3}{|l|}{ 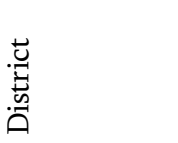 } & 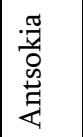 & 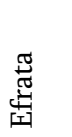 & 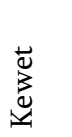 & 号 & 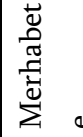 & 蛋 \\
\hline \multirow{4}{*}{ 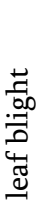 } & \multirow{2}{*}{$\begin{array}{l}0 \\
\stackrel{\sim}{\circ}\end{array}$} & Prev & 100 & 100 & 100 & * & * & * \\
\hline & & Sev & 8 & 6.17 & & * & * & * \\
\hline & \multirow{2}{*}{ 옥 } & Prev & 33.33 & 20 & 60 & 18.18 & 57.14 & 20 \\
\hline & & Sev & 6.67 & 10 & 10 & 7.5 & 7.81 & 2 \\
\hline \multirow{3}{*}{ 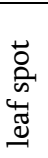 } & \multirow{2}{*}{$\stackrel{0}{\circ}$} & Prev & 50 & 100 & 60 & * & * & * \\
\hline & & Sev & 11.5 & 8.85 & 25 & * & * & * \\
\hline & $N$ & Prev & 44.44 & 20 & 60 & 45.45 & 0 & 0 \\
\hline
\end{tabular}




\begin{tabular}{|c|c|c|c|c|c|c|c|c|c|}
\hline & & Sev & \begin{tabular}{|l}
16.56 \\
\end{tabular} & 12.5 & 11.9 & 15 & & ( & 0 \\
\hline \multirow{4}{*}{ 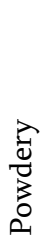 } & & Pre & 50 & 28.57 & 4 & * & & * & * \\
\hline & & Sev & 5 & 6.25 & 17. & * & & * & * \\
\hline & \multirow{2}{*}{ 귱 } & Pre & 22.22 & 20 & 13.3 & 36.3 & & ( & 0 \\
\hline & & Sev & 8.13 & 2.5 & 4.3 & 6.2 & & 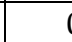 & 0 \\
\hline \multirow{4}{*}{ 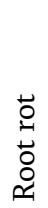 } & \multirow{2}{*}{$\begin{array}{l}0 \\
\stackrel{0}{\circ}\end{array}$} & Pre & 0 & 0 & & * & & * & * \\
\hline & & Inc & 0 & 0 & & $*$ & & * & * \\
\hline & \multirow{2}{*}{ 옹 } & Pre & 0 & 0 & ( & ( & & 14.2 & 0 \\
\hline & & Inc & 0 & 0 & ( & ( & 0 & 6.4 & 0 \\
\hline
\end{tabular}

Prev.: prevalence, Sev: severity, Iinc: incidence and * districts were not assessed due to early maturing of the crops

\section{B. Prevalence and Intensity of Mung Bean Insect Pests in Surveyed Areas}

Survey result showed, in the main season of 2016, 17 fields of mung bean were assessed from three districts of North shewa Zone (Table 2 and 3). Apion, grass hopper, leaf minor, stripe beetls and thrips were widely distributed across surveyed districts in 2016. The prevalence's of apion were 83.33, 42.86 and 83.33\% in Antsokia, Efratagidm and Kewet districts, respectively, with the corresponding severities of 22.22, 14.78 and 22.22\%.Grass hopper also the most commonly encountered pest, found in $77.78 \%$ of the fields surveyed. Similarly, the mean prevalence's i.e. $49.21,15.88,38.10$ and $25.40 \%$ were recorded from bugs, leaf minora, stripe beetles and thrips, respectively.

In 2017 the mean prevalence of apion was $87.80 \%$ with mean severity of $35.86 \%$ in assessed districts (Table 2 and 3). Regarding severities of apion, the consequent percent severities (15.87, 18.89, 17.03, 15.5, 17.9 and 8.88\%) were recorded from Antsokia, Efratagidm, Kewet, Ensaro, Merhabete and Midaweremo districts. On the other hand, ball worm was observed only in 2017 with mean prevalence's and severities of 71.43,10.67 (at Antsokia), 50, 3.89\% (at Efratagidm), 41.66, 15.55\% (at Kewet), 16.67,
$11.11 \%$ (at Ensaro) and 11.11, 2.22\% (at Merhabete) districts, respectively. With regard to mung bean bugs, it was prevalent only at Merhabete district with mean severity of $11.11 \%$ in 2017.

Accordingly, the insect distribution and intensity differed in each district and season. These differences can be attributed to differences in the distribution of host plants, the growth stage of host plants, pest control and cropping patterns in the area (Evans et al. 2013). The pest's species present in the mung bean fields in North Shewa Zone were Apion, grass hopper, bugs, ball worm, leaf minor, stripe beetles, thrips and beetles. These pests attack several species in the family Leguminosae, such as soybeans, mung beans, peanuts, pigeon pea, cowpea, common beans (Tengkano 1986).

Among these pests, Apion clavipes was the most important pests in all mung bean fields at both seasons. A.clavipes has become a regular pest North Shewa Zone (Kewet district) since 2012/13 cropping season (DBARC unpublished) especially during main cropping season. Indati et al., (2017), reported that in India, Apion clavipes is an important pest in mung beans and it may cause damage pods up to $49 \%$. It was also reported as a major pest of pigeon pea (Thakur et al., 2012) and mung bean from India (Ta1war 2014). Currently, this pest has spread to all districts of North Shewa Zone that grow mung bean.

\section{Frequencies and Densities of Mung Bean Weds in Surveyed Areas}

A total of 27 weeds were observed from mung bean fields in the surveyed area in 2016 and 2017 cropping season. The frequency of occurrence of individual weed species ranged from 3.2\% (Anagallis aruense) up to 65\% (Cyperus spp and Amaranthus spp), while the density ranged from 0.05 (Capsella burseparstoris(L .)) up to 43.93 (Cyperus spp.) per $\mathrm{m}^{2}$ in 2016 (Table 4). In 2016, Cyperus spp. was observed frequently with mean frequency (65\%) and density 
$\left(43.93 / \mathrm{m}^{2}\right)$. Regarding weed frequency, Amaranthus spp. also had the highest frequency (65\%) with mean density of $2.51 / \mathrm{m}^{2}$.

Also, in 2017, the frequency of individual weed species ranged from $3.2 \%$ up to $77.42 \%$, while the density of weed per $\mathrm{m}^{2}$ ranged from 0.4 to 16.11 (Table 4). Weed Spps. Cyperus rotundus and Echinoclo acolona L. were more frequently obtained weeds of mung bean in the surveyed districts with the consequent frequencies $(77.42,70.97 \%)$ and densities (16.11, 2.8 per $\mathrm{m}^{2}$ ).

The survey revealed that Cyperus spp.was frequently observed weed in both seasons with the highest weed density per $\mathrm{m}^{2}$. This implies that, it is economical importance of this weed for mung bean production in surveyed districts. Whereas, Echinoclo acolona L was most frequent weed in 2017 next to Cyperus rotundus. During the field survey it was observed that weed spp. frequency and density varied with season and location.

Though some weeds, such as Parthenium spp. had low frequency (Table 4), they were considered to be problematic weeds. Thus, high frequency does not indicate the economic or sociological importance of a weed species, as some weeds have other uses, such as feed for livestock, which can be especially important in the lowland areas.

Table 2: prevalence's and severities of mung bean insect pests in Antsokia, Efratagidm and Kewet districts

\begin{tabular}{|c|c|c|c|c|c|c|c|c|c|c|c|c|}
\hline \multirow{3}{*}{$\begin{array}{l}\text { Insect } \\
\text { pests }\end{array}$} & \multicolumn{4}{|c|}{ Antsokia } & \multicolumn{4}{|c|}{ Efratagidm } & \multicolumn{4}{|c|}{ Kewet } \\
\hline & \multicolumn{2}{|c|}{2016} & \multicolumn{2}{|c|}{2017} & \multicolumn{2}{|c|}{2016} & \multicolumn{2}{|c|}{2017} & \multicolumn{2}{|c|}{2016} & \multicolumn{2}{|c|}{2017} \\
\hline & 离 & 离 & 总 & d & 㐫 & 岕 & $\stackrel{己}{\beth}$ & 岕 & 己 & ڤె & $\stackrel{己}{\beth}$ & \\
\hline 1 & 옹 & $\begin{array}{l}m \\
m \\
m\end{array}$ & $\stackrel{0}{8}$ & & ชิ & $\stackrel{\infty}{+}$ & 용 & $\stackrel{\infty}{\infty}$ & $\begin{array}{l}\infty \\
\ddot{\infty} \\
\infty\end{array}$ & ָี & 옷 & \\
\hline
\end{tabular}

\begin{tabular}{|c|c|c|c|c|c|c|c|c|c|c|c|c|}
\hline $\begin{array}{l}\text { Ball } \\
\text { worm }\end{array}$ & $\stackrel{0}{0}$ & $\stackrel{0}{0}$ & $\stackrel{t}{i}$ & $\hat{0}$ & $\stackrel{0}{0}$ & $\stackrel{\circ}{0}$ & $\stackrel{\circ}{\circ}$ & gे & 0 & O․ & $\stackrel{\curvearrowright}{\rightleftarrows}$ & 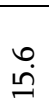 \\
\hline Bugs & 8 & $ت$ & O̊. & O. & $\stackrel{m}{ \pm}$ & 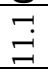 & 웅 & 0 & io & ت & $\stackrel{0}{0}$ & ㅇ. \\
\hline $\begin{array}{l}\text { Grass } \\
\text { hoppe } \\
\mathrm{r}\end{array}$ & சृ & $\stackrel{m}{m}$ & $\begin{array}{l}\hat{y} \\
\text { y }\end{array}$ & 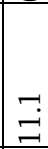 & Oீ. & $\underset{ٌ}{\stackrel{m}{+}}$ & ㅇ. & 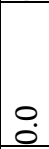 & ô & $\begin{array}{l}n \\
\ddot{n} \\
m\end{array}$ & ㅇ. & $\stackrel{0}{0}$ \\
\hline \begin{tabular}{|l} 
Leaf \\
minor
\end{tabular} & $\widehat{\sigma}$ & تב & $\stackrel{0}{0}$ & ○. & $\underset{ \pm}{\stackrel{n}{+}}$ & ב & $\stackrel{0}{0}$ & $\ddot{0}$ & бo & $\stackrel{\longrightarrow}{\rightleftarrows}$ & $\underset{\sigma}{\sigma}$ & $\ddot{m}$ \\
\hline $\begin{array}{l}\text { Stripe } \\
\text { beetls }\end{array}$ & $\begin{array}{l}0 \\
\text { in }\end{array}$ & $ت$ & O. & $\stackrel{0}{0}$ & $\underset{+}{n}$ & ב & $\stackrel{0}{0}$ & $\begin{array}{l}0 \\
0 \\
\end{array}$ & $\begin{array}{l}0 \\
0 \\
i n\end{array}$ & 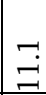 & $\stackrel{\curvearrowright}{F}$ & તี \\
\hline Thrips & $\underline{6}$ & 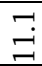 & $\begin{array}{l}1 \\
\infty\end{array}$ & o. & $\begin{array}{l}\hat{y} \\
\text { y }\end{array}$ & 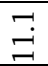 & $\begin{array}{l}\circ \\
\text { in }\end{array}$ & ָָ & $\widehat{\sigma}$ & 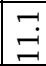 & $\begin{array}{l}n \\
\infty \\
\infty\end{array}$ & $\stackrel{0}{0}$ \\
\hline Beetls & $\stackrel{0}{0}$ & ㅇ. & $\stackrel{n}{+}$ & 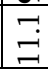 & 0 & $\stackrel{0}{\circ}$ & ำ & g. & 0 & 0 & $\stackrel{0}{0}$ & O̊. \\
\hline
\end{tabular}

Prev.: prevalence, Sev.: severity, Iinc.: incidence and ${ }^{*}$ districts were not assessed due to early maturing of the crops

Table 3: prevalence's and severities of mung bean insect pests in Ensaro, Merhabete and Midaweremo districts

\begin{tabular}{|c|c|c|c|c|c|c|c|c|c|c|c|c|}
\hline \multirow[t]{3}{*}{ Insect pests } & \multicolumn{4}{|c|}{ Ensaro } & \multicolumn{4}{|c|}{ Merhabete } & \multicolumn{4}{|c|}{ Mida } \\
\hline & \multicolumn{2}{|c|}{2016} & \multicolumn{2}{|c|}{2017} & \multicolumn{2}{|c|}{2016} & \multicolumn{2}{|c|}{2017} & \multicolumn{2}{|c|}{2016} & \multicolumn{2}{|c|}{2017} \\
\hline & 离 & $\vec{\sim}$ & 己. & $\vec{W}$ & $\begin{array}{l}\vec{D} \\
D_{1} \\
D\end{array}$ & $\vec{\sim}$ & 总 & $\vec{\sim}$ & 己. & ڤ & 离 & 岕 \\
\hline Apion & * & * & $\hat{\theta}$ & $\begin{array}{l}n \\
\text { In }\end{array}$ & * & * & Оं & ㄱ. & * & * & 요 & $\begin{array}{l}9 \\
\infty \\
\infty\end{array}$ \\
\hline Ball & * & * & $\stackrel{\sigma}{\sigma}$ & $\vec{Z}$ & * & * & $\rightleftarrows$ & ָั & * & * & $\stackrel{\circ}{0}$ & 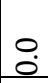 \\
\hline Bugs & $*$ & * & $\stackrel{\circ}{\circ}$ & $\stackrel{\circ}{\circ}$ & $*$ & * & $\stackrel{7}{\rightleftarrows}$ & $\stackrel{\rightleftarrows}{\rightleftarrows}$ & * & $*$ & $\stackrel{\circ}{0}$ & O. \\
\hline Grasshoppe & * & * & $\hat{\sigma}$ & તี & * & * & 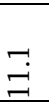 & ָั & * & * & $\ddot{0}$ & $\ddot{0}$ \\
\hline Leafminor & * & * & $\stackrel{0}{\circ}$ & 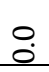 & * & * & $\stackrel{\circ}{\circ}$ & $\stackrel{\circ}{0}$ & * & * & $\ddot{0}$ & 0 \\
\hline $\begin{array}{l}\text { Stripe } \\
\text { beetls }\end{array}$ & * & * & $\stackrel{0}{0}$ & $\stackrel{0}{0}$ & * & * & $\stackrel{0}{0}$ & $\stackrel{0}{0}$ & * & * & $\stackrel{0}{0}$ & $\ddot{0}$ \\
\hline Thrips & $*$ & * & $\underset{8}{0}$ & $\stackrel{9}{=}$ & * & * & $\stackrel{\circ}{\circ}$ & $\stackrel{\circ}{\circ}$ & * & * & $\stackrel{0}{0}$ & 0 \\
\hline Beetls & $*$ & * & O. & $\stackrel{\circ}{\circ}$ & * & * & ־ & $\stackrel{\rightleftarrows}{\rightleftarrows}$ & * & * & $\stackrel{0}{0}$ & O. \\
\hline
\end{tabular}

Prev.: prevalence, Sev.: severity, Iinc.: incidence and * districts were not assessed due to early maturing of the crops

Table 4: Frequencies and densities of mung bean weeds in North Shewa Zone 


\begin{tabular}{|c|c|c|c|c|c|}
\hline \multicolumn{2}{|l|}{\begin{tabular}{|l} 
Weeds \\
\end{tabular}} & \multicolumn{2}{|l|}{2016} & \multicolumn{2}{|l|}{2017} \\
\hline Local name & Scientific name & $\begin{array}{l}\mathrm{F} \\
(\%)\end{array}$ & \begin{tabular}{|l|}
$\mathrm{D}$ \\
$/ \mathrm{m}^{2}$
\end{tabular} & \begin{tabular}{|l|}
$\mathrm{F}$ \\
$(\%)$
\end{tabular} & $\begin{array}{l}\mathrm{D} \\
/ \mathrm{m}^{2}\end{array}$ \\
\hline Engicha & Cyperusrotundus L. & 65.0 & $\begin{array}{l}43 . \\
9\end{array}$ & 77.4 & $\begin{array}{l}16 . \\
1\end{array}$ \\
\hline Teseri & cilianensis & 8.1 & 0.1 & 71.0 & 2.8 \\
\hline Wofankur & $\begin{array}{l}\text { Commelinabenghalensis } \\
\text { L. }\end{array}$ & 16.7 & 0.1 & 45.2 & 0.9 \\
\hline Aluma & Amaranthusalbus & 65.0 & 2.5 & 41.9 & 1.7 \\
\hline Besobila & $\begin{array}{l}\text { Justiciahetrocarpa-linda- } \\
\text { Acanthaceae }\end{array}$ & 8.3 & 0.2 & 41.9 & 1.1 \\
\hline Yemognfikr & Xanthium strumarium L. & - & - & 38.7 & 4.1 \\
\hline Serdo & Cynodondactylon & 25.0 & 6.6 & 35.5 & 3.5 \\
\hline Kechekech & Polygonumaviculare & 35.0 & 2.1 & 25.8 & 1.5 \\
\hline Kosheshila & Echinopscornigerus & 51.7 & $\begin{array}{l}20 . \\
6\end{array}$ & 25.8 & 2.0 \\
\hline Parthinum & $\begin{array}{l}\text { Partheniumhysterophor } \\
\text { us }\end{array}$ & - & - & 19.4 & 3.3 \\
\hline Merarita & Sidaacuta L & - & - & 16.1 & 2.6 \\
\hline Muachera & Brachiariaeruciformis & 41.7 & 6.7 & 6.5 & 4.0 \\
\hline unkown & Acanthospornum & 18.3 & 0.5 & 6.5 & 0.4 \\
\hline Antaria & Euphorbia hirta L. & - & - & 3.2 & 0.4 \\
\hline Asendabo & Phalarisparadoxa L. & - & - & 3.2 & 1.2 \\
\hline Yetjasiga & Chenopodium album & - & - & 3.2 & 3.0 \\
\hline Yesetmilas & Anagallisaruense & 3.2 & $\begin{array}{l}11 . \\
4\end{array}$ & - & - \\
\hline Chegogit & $\begin{array}{l}\text { Xanthium Strumarilum } \\
\text { L. }\end{array}$ & 45.0 & 6.1 & - & - \\
\hline Beganefssie & SeneciosteudelieAstracel & 16.7 & 0.5 & - & - \\
\hline Buahita & Oxygonumeruciformis & 16.7 & 0.2 & - & - \\
\hline Etsefaris & Dathuraspp & 16.7 & 1.4 & - & - \\
\hline Geso & $\begin{array}{l}\text { Capsella burse- } \\
\text { parstorisL. }\end{array}$ & 8.3 & 0.1 & - & - \\
\hline Kermame & Pupalialappace L. Juss & 33.3 & 4.8 & - & - \\
\hline Unkown & Vernoniabipontini(vake) & 20.0 & 2.3 & - & - \\
\hline Wushana & Oxygonumsinuatum & 8.3 & 0.3 & - & - \\
\hline Yejibchama & Cyathulaprostrate L. & 16.7 & 1.0 & - & - \\
\hline $\begin{array}{l}\text { Yewshasinde } \\
\text { do }\end{array}$ & Setaria spp. & 30.0 & 0.7 & - & - \\
\hline
\end{tabular}

F: frequency, D: density weeds with their local name will be changed to their scientific name after identification completed by Ambo plant protection Research center

\section{CONCLUSIONS AND RECOMMENDATION}

The study confirmed that mung bean grown in all surveyed districts of North Shewa Zone with different level of production coverage. Furthermore, the crop was found to be infected with different pests and therefore prone to various diseases, insect pests and weeds. During the survey, four diseases, eight insect pests and around 27 weeds were observed on mung bean fields. Even though the yield loss caused by each pest is not clearly studied and quantified in studied crop and areas, this study indicate the presence of complex of pests at different levels in the surveyed districts.

\section{ACKNOWLEDGMENTS}

I am pleased for Debre birhan agricultural Research Center for financial and logistics support. I am also great full to Ambo Plant Protection Research Center (APPRC) for assisting in weed identification.

\section{REFERENCES}

[1]. AsratAsfaw,

FekaduGurum, AlemayehuShenkute, and YayisRezene 2012. Analysis of multi-environment grain yield trials in mungbean vigna radiate(1.) Wilczek based on ggebipot $\mathrm{n}$ Southern Ethiopia.Journal of Agricultural Science and Technology 14: 389398

[2]. Boudreau, M.A. and Mundt, C.C. 1992. Mechanisms of alteration in bean rustepidemiology due to intercropping with maize. Psychopathology 82: 1051-1060.

[3]. CSA (Central Statistical Authority). 2017. Report on Area and Production of Major Crops. Statistical Bulletin. Addis Ababa, Ethiopia: CSA.

[4]. Das S., Shekhar UD. andGhosh P. 2014. Assessment of molecular genetic diversity in some green gram cultivars as revealed by ISSR 
analysis.Advances in Applied Science Research 5(2): 93-97.

[5]. Ethiopian Commodity Exchange (ECX). 2014. Ethiopia Commodity Exchange Rings Bell for mungbean Addis Ababa.

[6]. Hussain F., Malik AU., Haji MA. andMalghani AL. 2011. Growth and yield response of two cultivars of mungbean (Vignaradiata L.) to different potassium levels. Journal of Animal and Plant Sciences 21(3): 622- 625.

[7]. Indati S.W., Bejo and Rahayu M. 2017.Diversity of mung bean insect pests and their natural enemies in farmers' fields in East Java, Indonesia.Biodiversitas18 (4): 1300-1307.

[8]. Jat SL., Prasad K. and Parihar CM. 2012.Effect of organic manuring on productivity and economics of summer mungbean (Vignaradiata Var. radiata). Ann Agric Res New series 33(12): 17-20.

[9]. Khan MA., Naveed K., Ali K., Ahmad B. and Jan S. 2012. Impact of mungbean-maize intercropping on growth and yield of mungbean. Weed science society of Pakistan department of weed science. Journal of Weed Science Research 18(2): 191-200.

[10]. Kumari R, Shekhawat KS, Gupta R, Khokhar MK 2012.Integrated management against rootrot of mungbean (Vignaradiata L.)Wilczek) incited by macrophominaphaseolina. Journal of PlantPathology and Microbiology 3: 136. doi:10.4172/2157-7471.1000136

[11]. Minh NP. 2014. Different factors affecting to mungbean (Phaseolusaureus) tofu production. International Journal of Multidisciplinary Research and Development 1(4):105-110.

[12]. Pandey A., Kumar A. and Ramya P. 2011. Genetic diversity in green gram accessions as revealed by STMS markers. African Journal of Biotechnology 10(75):17081-17087.
[13]. Poehlman, J.M. 1991. The mung bean. Westview Press, Boulder, San Franscisco, Oxford.pp. 1-338

[14]. Ramanathan, A., Vidhyasekaran, P. and Rathinakumar L. 2002. Selection of Powdery Mildew and Yellow Mosaic Resistant Green gram Plants regenerated through Organogenesis. Archives of Phytopathology and Plant Protection.,35:105-114.

[15]. Roger Nkoa, Micheal D. K. Owen, and Clarence J. Swanton 2015. Weed abundance, distribution, diversity, and community analyses.Weed Science Society of America, 63(1):64-90.

[16]. Sehrawat N., BhatKV.,Sairam RK. andPawan KJ. 2013. Identification of salt resistant wild relatives of mungbean (Vignaradiata L.) Wilczek).Asian Journal of Plant Science and Research 3(5): 41-49.

[17]. Srinives, P. 1996. Mungbeanbreeding : Past, present and future. pp. 73-82. In MungbeanGermplasm : Collection, Evaluation and Utilization for Breeding Program. Proceedings of the Workshop on MungbeanGermplasm held at Bangkok, Thailand on August 17, 1995. JIRCAS.

[18]. Suli Sun, Ye Zhi, and Zhendong Zhu 2017. An emerging disease caused by pseudomonas syringaepv. Phaseolicola threatens mung bean production in China. Journal of Plant Disease 101:95-102

[19]. Talwar, N. 2014. Comparative biology of fruit and root feeding weevils of India: a review (Coleoptera: Curculionidae).International Journal of Science and Technology, 3(3); 988992.

[20]. Tengkano W. 1986.Identification and bioecology of insect pest of soybean and mungbean. Training Course on Integratrd Pest Management of Legumes and Coarse Grains. FAO Biotrop.Bogor, July 15 Agust, 1986. 
[21]. Thakur, N.S.A. Firake, D.M. Behere, G.T. Firake, P.D. andSaikia, K. 2012. Biodiversity of Agriculturally Important Insects in North Eastern Himalaya: An Overview.Indian Journal of Hill Farming, 25(2); 37-40.

[22]. Yagoob H. and Yagoob M. 2014. The effects of water deficit stress on protein yield of mungbean genotypes. Peak Journal of Agricultural Science 2(3): 30-35.

\section{Cite this article as :}

Wulita Wondwosen, "Assessment of Mung Bean (Vignaradiata) pests in the Low Land Areas of North Shewa Zone", International Journal of Scientific Research in Science and Technology (IJSRST), Online ISSN : 2395-602X, Print ISSN : 2395-6011, Volume 6 Issue 3, pp. 97-104, May-June 2019. Available at doi : https://doi.org/10.32628/IJSRST1962155 Journal URL : http://ijsrst.com/IJSRST1962155 